\title{
Academic Libraries in Iran
}

\begin{abstract}
Iranian librarianship is in the embryonic stages of development, especially with respect to modern and functional academic libraries. In three major areas-personnel, resources, and physical facilities-the academic libraries are deficient compared with Western standards. Although all major cities of Iran do have either a college, university, or technical library, the best academic libraries are to be found at the University of Tehran, Pahlavi University, and the University of Isfahan.
\end{abstract}

$T$ HE MODERN CONCEPT of librarianship as a professional career is largely a development of the last decade in Iran. Though her cultural and educational heritage is an ancient and distinguished one, the idea of attractive, functional libraries open to the public is a recent innovation, and one that is still being tested as it develops. Libraries have flourished in Iran for many centuries, but it is only recently that efforts have been made to adopt Western methods and techniques, and to encourage independent study and leisure reading beyond the traditional memorization of textbooks. ${ }^{1}$ The purpose of this paper is to survey some of the recent developments in academic librarianship in Iran, and to assess some of its strengths and weaknesses. ${ }^{2}$

Iran's modern educational system may be said to date from the establishment of the College of "Darol-Fonon" (House of Sciences), founded in the capitol city of Tehran (1850)..$^{3}$ A number of British, Austrian, French, Polish, and Italian instructors were brought there to teach technical and scientific subjects. The college began with 100 se-

Mr. Deale is director of libraries, Beloit College, Beloit, Wisconsin. lected students, all sons of nobility. Later the curriculum was expanded and three foreign languages (English, French, and Russian) together with painting and music, were added. In 1858 there was created a Ministry of Sciences and Fine Arts, and a few years later (1862), a special bureau of translation, attached to the Court of the Shah, for the purpose of translating important European books into the Persian language. It was just a century ago (1873) that the first official library, called the Royal Library since it was attached to the Court, was inaugurated. A society "for the establishment of the national schools" was founded in 1897, thereby providing the first free schools throughout the country. In this same year, the National Library was begun, and two years later, a college of political science and an agricultural college were opened under government auspices. ${ }^{4}$

Although the Constitution of 1906 and later laws passed in 1910 underscored the government's responsibilities and concern for education, it was not until the reign of Reza Shah, father of the present ruler, that any great impetus was given to education. Not only was he responsible for the founding of state schools, teachers' training colleges, tech- 
nical colleges, and a modern university in Tehran, but he also dispatched hundreds of scholarship students abroad for further study. Universal free primary education came with legislation passed in July 1943. The tremendous growth of both primary and secondary education since World War II, and the government's continued efforts to wipe out illiteracy, give indication of its concern for education. ${ }^{5}$

In the middle of the nineteenth century, university education was remodeled along the lines of the French system. Several university "colleges" were established in Tehran and functioned independently until 1934. In that year they were merged to form the present University of Tehran. During the academic year, 1968-1969, some 50,000 students attended forty-four Iranian institutions of higher education. ${ }^{6}$ Over 20,000 students are studying in other countries, a majority of these in the United States. Major provincial universities, created since 1934, have followed the pattern set by the University of Tehran, and many aspects of higher education are being influenced by American practice. ${ }^{7}$ This brief background will serve as an introduction to the major aim of this discussion: a consideration of academic librarianship in Iran.

The best of Iranian libraries are connected with the universities or with the government ministries. In spite of an increasing acknowledgment by administrators and younger faculty that libraries are essential, and must receive greater support, most academic libraries are understocked, poorly managed, and contribute little to the education of the student.

It is difficult to expect otherwise, as Slocum comments, "in a country in which librarianship has no status, in which there are literally only a handful of professional librarians, and in which the educational system is based on the memorization of textbooks." 8 There are exceptions, of course, and in the last five years alone the number of professional librarians has more than quadrupled. In the universities, each independent "faculty" has its own collection of books and periodicals, with the result that there is often duplication of materials and insufficient coverage of major fields of learning. The students are not, for the most part, encouraged to use libraries; those who might wish to do so find it difficult. There are few libraries with open shelves, card catalogs are generally inadequate, and the subprofessional staff is not equipped to give reference service. Only two universities in all of Iran have firmly established the position of director of libraries. ${ }^{9}$ As recently as 1970 , the oldest and largest institution in the country (the University of Tehran) had head librarians for each of its faculty libraries, but no coordination of library administration. Few Iranian academic libraries would measure up to American standards for college libraries, but it is perhaps unfair to make such comparison at this stage in their development.

Let us proceed now to an examination of the three major areas of academic librarianship, and survey the strengths and weaknesses of several typical libraries.

The most crucial problem facing Iranian librarianship today, and in the immediate future, is that of personnel. "The development of university libraries requires above all the intellectual and professional services of men and women who have been trained for precisely such purposes-expert librarians." 10 In part it is a problem for the universities and government to solve, but also one of major concern to the embryonic library profession of Iran. ${ }^{11}$ In 1965, according to the best estimates available, there were no more than a dozen trained librarians (master's degree in library science) in the entire country; today there are approximately 
100 , most of them in the various libraries located in Tehran. There are insufficient Iranian professionals to fill the top positions in the country's academic libraries. The heads of the four "faculty" libraries at Pahlavi University, for example, are all Americans on temporary appointments. For the past five years there has been a Fulbright professor on the library science faculty at the University of Tehran. For one thing, it is difficult to find candidates whose academic and scholarly qualifications are sufficiently high to qualify them for admission to graduate schools of library science. One of the solutions to the personnel problem will be to seek out such individuals, sending them abroad for the master's degree, or encouraging them to apply for admission to the library science program at the University of Tehran. Though there are also several other library schools in the Middle East most Iranians prefer to study in the United States if they can meet admissions requirements and secure the necessary funds to support themselves for the duration of their study abroad. ${ }^{12}$

One of the more significant developments of the past five years was the establishment of Iran's first formal instruction program in library science. In 1966, Alice Lohrer, associate professor at the Graduate Library School, University of Illinois, with the able assistance of Iranian colleagues, organized the Department of Library Science in the Faculty of Education, University of Tehran. The purpose of the new program was to provide professional library education for the University's own library staff members, to provide professionals for other developing institutions of higher education, and also to provide some understanding of library use for future teachers. ${ }^{13} \mathrm{~A}$ four-year bachelor's degree and proficiency in English were required for admission to this two-year, 36 semester-credit-hour, master's degree curriculum. English was chosen as the language of instruction since the senior instructors (at that time) were American Fulbright professors who taught in teams with Iranian colleagues who were expected eventually to take over all administration and instruction. Most of the classes are now taught in Persian (Farsi), except in cases where there is a foreign instructor. Perhaps a more valid reason for using English would be the lack of library science materials in Persian, and that without a reading knowledge of English students would be handicapped. The program was designed to combine the best features of American library education with the needs of Iranian librarians. In the summer of 1968 the department added an undergraduate minor. This was intended for students in Education and other fields who could prepare to become teacher-librarians and public library assistants. Students still have some difficulty adapting to modern methods of instruction (without textbooks), and still try to take notes verbatim and to review by memorizing all assignments.

In academic libraries the nature and size of the staff is affected by such factors as number of students, faculty, size and design of library, the character and condition of the book collection, branch collections, hours, teaching methods, etc. Staff members in most Iranian academic libraries are subprofessionals or clerks without the benefit of either long experience or graduate study. Thus, the primary need is for administrators, reference librarians, catalogers, and faculty for the library science program. Each year there are a few more graduates who receive degrees from abroad; each year there are a few more graduates from the newly developing library school at the University of Tehran, but the demand for trained personnel exceeds the supply, and will continue to do so for some years. Possible solutions? One is to break down the tradition that 
most Iranian young people become doctors, engineers, or lawyers. There must be a concerted campaign for the recruitment of capable young men and women who will choose a career in librarianship. At the same time, there must be efforts made to improve the status and remuneration of those who make the effort to secure the master's degree in library science. Professional librarians trained in a foreign country now receive about 3,000 tomans $(\$ 400)$ per month; while those who received a degree in Iran find there is a 500 toman differential $(\$ 75)$ in their monthly salary. University officials should seriously consider subsidizing one or more candidates annually for the master's degree in library science, making it a condition of the grant that the individual return to that institution for at least two years of service. Through the Fulbright program, and other outside assistance, foreign librarians (as lecturers and consultants) have been a temporary solution to the shortage of librarians, but the day must soon come when there is no longer the need for such assistance. Guidelines must be established for staffing of academic libraries, ensuring adequate coverage in the first instance, and a basis for future planning and financing. ${ }^{14}$ Problems of personnel will continue to plague Iranian academic libraries if librarianship is looked upon as a second-rate profession, without equal status and compensation to that of the teaching faculty.

A second major problem that exists in Iranian academic libraries is the size and quality of their collections. Because of the traditional textbook method of teaching, and the indifference to libraries in general, most academic library collections in Iran have been useless. Books are purchased haphazardly, catalogued chaotically, and shelved by any convenient system (including date of acquisition). Most card catalogs are hopelessly inadequate, and there have been almost no other aids, such as indexes and bibliographical guides, for the location of material. Open shelves are a recent innovation; there is a lack of scholarly periodicals and reference materials; reference and bibliographical works that do exist are almost entirely in foreign languages (useless to a majority of students).

The scene is gradually changing, however, and the role of the library in higher education is recognized. The institution with the largest collection is, of course, the University of Tehran, with resources totaling some 275,000 volumes and manuscripts. These materials are dispersed among thirty departmental or "faculty" libraries, though a central library collection has now been established with the opening of the university's new central library building (completed 1970). Two other universities in Iran have collections of approximately 100,000 volumes, though the quality of these resources at Pahlavi and Isfahan universities is dubious. Other academic institutions have collections of under fifty thousand volumes, and probably lack the basic resources to support subjects in their own curricula. ${ }^{15}$

A part of the problem in providing adequate resources stems from the practice of making the deans responsible for the distribution of funds. In most cases there is no published library budget, no director of libraries, and no regular book funds for annual support or development of collections. In one particular case, the chancellor informed me that a reasonable sum was available for books during the current year. He neglected to add that this modest amount also covered periodical subscriptions, binding, or duplicates for reserve. According to the library staff less than five thousand dollars was actually available for the purchase of books that year. In another situation, the administration found it expedient to spend a sizable amount on a special collection of old 
newspapers (unbound), but the librarians didn't even know how much was available for books. It is essential that book funds be provided annually, that restrictions on imports and currency be modified, and that cumbersome postal procedures be overhauled. The acquisition of materials in the Middle East is a tedious and frustrating process at best, presenting daily obstacles to library growth and development.

In nearly all the academic libraries I visited, there was need for some kind of "standards" in the selection of materials. Assuming that the university grants the library staff responsibility and authority for book selection and acquisition, a close working relationship must be cultivated with the teaching faculty.

The third major area essential to good academic library service is that of physical facilities. A balanced staff is not enough; a basic book collection, however well-selected and funded, is not enough; there must also be attractive, functional facilities for effective library service. Though the physical facilities of Iranian academic libraries are often impressive, too often they have been planned and executed without adequate consultation among librarian, architect, and university administrators. Appearance is all-important in the Iranian concept, and one frequently wonders whatever happened to the principle that "form follows function." Regardless of exterior or interior embellishment, the most successful library buildings have been those which clearly and directly express and provide for the functions that are performed within them.

One of the largest university libraries in the Middle East has just been completed on the University of Tehran campus. Its book capacity is one-half million, and though it will ultimately rise to a height of ten stories, its design seems to stress monumentality rather than simple function. Nevertheless, it is impressive, even by western standards of construction.

At Pahlavi University's new mountain-side campus, a six-million-dollar library is presently being built. Located at the pinnacle of the campus, it will eventually be surrounded by other academic buildings already planned for the site. The present library at Pahlavi was planned and constructed while I was acting director of libraries (1965-66), and is a modest, cement-block structure on one level, with two large reading rooms on either side of a central circulation counter. Two additions have been necessary in the past five years due to the heavy use of the library by students. In addition to this central library, Pahlavi has new libraries for both engineering and agriculture faculties, and its excellent Medical Library has expanded as far as it possibly can in its present quarters in the main building of the Faculty of Medicine.

The present University of Isfahan is in the process of building an entirely new campus, and there are many inconveniences caused by the fact that its libraries are scattered in various parts of the city at the present time. Already there are several attractive modern buildings on the new campus, with temporary libraries located in three of them. Though they provide large reading rooms, no imagination has been shown in the arrangement of stacks, offices, or furnishings; in fact, the branch libraries all look alike. Each of the libraries have closed stacks, no professional staff, and no evidence of reference service. According to the director of libraries, provision is being made to open up the stack areas and to rearrange the check-out counter for proper control of egress. Though a new central library is on the drawing boards for this rapidly developing campus, the central collection remains on the downtown campus and houses about 40 percent of all library resources. It has a depressing in- 
terior, is poorly arranged, and is certainly inconvenient for student use. Eventually the University of Isfahan should be the equal of Pahlavi and the University of Tehran.

Among the smaller academic institutions, Damavand College (formerly the Iran Bethel School for Girls) has made good use of its limited space in the basement of the school's main building in the heart of downtown Tehran. Future plans call for a new campus in suburban Tehran, enlarging all aspects of the college on a campus designed by Frank Loyd Wright Associates. Reportedly the first major building, for which funds are available, will be the library. The administration at Damavand appears to be progressive, and the president was anxious that plans for the library be carefully evaluated by a professionallytrained librarian. Another small college, catering to middle-class Iranian young women, is Iranian Girls College, located on a lovely campus in north Tehran. The physical facilities of its library are impressive, with one of the most attractive and functional reading rooms of any Iranian library visited. However, there is no professional librarian in charge, and the staff consists of untrained clerks and former students. The budget is quite small, and the circulation of books per student is low.

Pars College, a private, liberal arts institution serving about 1,500 students, most of whom live in Tehran, is housed in three large older buildings in suburban Tehran. The librarian, one of the first graduates of the library science master's program at the University of Tehran, is doing a commendable job under difficult circumstances. The library, with less than 7,000 volumes, is located on the second floor of the Administration/classroom building; it is crowded, in need of more staff and more space for expansion. There is a second collection in one of the other buildings, and both parts of the library have been made as attractive as possible. Plans for a new campus, competently drawn by a firm of French architects, include a separate library building. No funds are in sight for its development.

Though no specific mention has been made of Tehran's National University, or the provincial universities at Mashad, Tabriz, Ahwaz, Kerman, or Rezayieh, the pattern is similar. By Western standards, most Iranian academic institutions are still in the stages of growth and development, while attempting to meet the needs of today's expanding student population. The urgency of, and the need for, college and university and technical education in a country that is moving rapidly into the twentieth century poses one of the biggest problems to educational planners in Iran. When the current "Fourth Plan" was prepared, it envisaged some 40,000 students applying for admission to institutions of higher education by 1972 ; it is now certain that the number will prove to be more than twice what had been anticipated. Though there are now colleges or universities in all the major cities of Iran, plans are already being made for the extension of these institutions, and for additional new ones in the decade of the seventies. ${ }^{16}$ With the development of higher education will come the development of libraries, but there is needed a dedicated effort on the part of Iran's core of professional librarians to see that modern librarianship is not ignored and that funds are made available from the government and other sources for staffing, collections, and buildings.

Furthermore, it will not be sufficient to provide libraries properly staffed, properly stocked, and properly funded. Iranians will need to be instructed in their use, encouraged to do more independent reading, and weaned from their traditional patterns of learning. It is an exciting and challenging period 
in Iran's social and cultural development, and it offers an opportunity to anyone who becomes in any way involved with it.

\section{REFERENCES}

1. "Public and private libraries under the Seleucids, who ruled from 320 to 261 B.C., and under the Parthians, from 250 B.C. to A.D. 226, contained large indexed parchment rolls and clay tablets all easily accessible to scholars."-Ibrahim V. Pourhadi, "Iran's Public and Private Libraries," Quarterly Journal of the Library of Congress 25:222 (July 1968).

2. The author has had Fulbright assignments in Iran on two separate occasions: At Pahlavi University, Shiraz (1965-66) and at the Department of Library Science at the University of Tehran (1970-71).

3. Iran Almanac and Book of Facts, 1970. Tehran, Echo of Iran, 1970.

4. Pourhadi. Iran's Public . . Libraries, p. 222: "The National Library . . was not officially opened until 1937, although it has large collections relating to the 16th and 17th centuries... obtained from private and public libraries dating back to the early sixteenth and seventeenth centuries."

5. Although approximately 75 percent of Tehran's population is literate, among the population outside the capitol this figure drops to 24.4 percent. The Shah's "Literacy Corps," and the building of more schools, is progressively combatting illiteracy. (Source: Iranian Statistical Center, $\mathrm{Na}$ - tional Census of Population and Housing, November 1966, Vol. 72: Total CountrySettled Population, March 1968, table 7, p. 19, and Vol. 10: Tehran Shahrestan, (August 1967), table 7, p. 66.

6. Iran Almanac and Book of Facts, 1970.

7. Pahlavi University in Shiraz, for example, is referred to as an "American type university."

8. Joel B. Slocum, Iran: A Study of the Educational System of Iran ..., Washington, D. C., Council on Evaluation of Foreign Students Credentials, 1969, p. 24.

9. Pahlavi University (Shiraz) and Isfahan University (Isfahan).

10. M. A. Gelfand, University Libraries for Developing Countries (Paris: UNESCO, 1968), p. 50.

11. The Iranian Library Association was officially established in October, 1966.

12. There are schools in Ankara, Beirut, and Tel Aviv.

13. Ali Sinai, and John Harvey, "The Iranian Library Scene," in International Library Review 1:107 (1969).

14. "Guidelines" are being developed by the Iranian Documentation Center, Tehran.

15. Iran Almanac, 1970.

16. See Ehsan Yar-Shater, Iran Faces the Seventies (N.Y.: Praeger, 1971), p. 21759. 